\title{
High bat (Chiroptera) diversity in the Early Eocene of India
}

\author{
Thierry Smith • Rajendra S. Rana • Pieter Missiaen • \\ Kenneth D. Rose • Ashok Sahni • Hukam Singh • \\ Lachham Singh
}

Received: 3 April 2007 /Revised: 15 June 2007 / Accepted: 25 June 2007 / Published online: 1 August 2007

(C) Springer-Verlag 2007

\begin{abstract}
The geographic origin of bats is still unknown, and fossils of earliest bats are rare and poorly diversified, with, maybe, the exception of Europe. The earliest bats are recorded from the Early Eocene of North America, Europe, North Africa and Australia where they seem to appear suddenly and simultaneously. Until now, the oldest record in Asia was from the Middle Eocene. In this paper, we report the discovery of the oldest bat fauna of Asia dating from the Early Eocene of the Cambay Formation at Vastan Lignite Mine in Western India. The fossil taxa are described on the basis of well-
\end{abstract}

\section{T. Smith $(\bowtie)$}

Department of Palaeontology,

Royal Belgian Institute of Natural Sciences,

rue Vautier 29,

1000 Brussels, Belgium

e-mail: Thierry.Smith@naturalsciences.be

\section{R. S. Rana $\cdot$ L. Singh}

Department of Geology, H.N.B. Garhwal University,

Srinagar 246175 Uttaranchal, India

P. Missiaen

Aspirant FWO Vlaanderen, Research Unit of Palaeontology,

University of Ghent,

Krijgslaan 281-S8,

9000 Ghent, Belgium

\section{K. D. Rose}

Center for Functional Anatomy and Evolution,

Johns Hopkins University School of Medicine,

Baltimore, MD 21205, USA

\section{A. Sahni}

Centre of Advanced Study in Geology, Panjab University,

Chandigarh 160014, India

H. Singh

Birbal Sahni Institute of Palaeobotany,

53 University Road,

Lucknow 226007, India preserved fragments of dentaries and lower teeth. The fauna is highly diversified and is represented by seven species belonging to seven genera and at least four families. Two genera and five species are new. Three species exhibit very primitive dental characters, whereas four others indicate more advanced states. Unexpectedly, this fauna presents strong affinities with the European faunas from the French Paris Basin and the German Messel locality. This could result from the limited fossil record of bats in Asia, but could also suggest new palaeobiogeographic scenarios involving the relative position of India during the Early Eocene.

Keywords Chiroptera · Mammalia · Early Eocene - Vastan · India

\section{Introduction}

The earliest known bats are from the Early Eocene of the Paris Basin in France (Russell et al. 1973), the Green River Basin in Wyoming (Jepsen 1966), Chambi in Tunisia (Sigé 1991), and Queensland, Australia (Hand et al. 1994). Until now, the oldest record of bats in Asia was based on one tooth discovered in the early Middle Eocene of Pakistan (Russell and Gingerich 1981), and the first real bat fauna was described from the late Middle Eocene of Yuanqu Basin, China (Tong 1997).

The recent discovery of a few isolated bat teeth in the Early Eocene of western India at Vastan Mine, Gujarat (Rana et al. 2005) prompted us to make new excavations at the locality. Vastan Lignite Mine northeast of Surat exposes the Cambay Formation, which is of middle-late Ypresian age based on the presence of Nummulites burdigalensis. The mammal fauna is composed of typical endemic groups, such as anthracobunids, as well as the first modern 
mammals of India, including primates, artiodactyls, and rodents (Bajpai et al. 2005a; Rose et al. 2006). The most abundant and diversified mammals discovered are the bats, which are represented by jaws, isolated teeth, and bones. The Vastan bats are the oldest bats of Asia and represent, together with the European bats, the oldest bat faunas ever found. This paper discusses the systematics of the bats, based on the lower dentition, to highlight the extraordinary diversity observed of these earliest bats. The upper dentition and bones that confirm this diversity will be described in a second more detailed paper with a phylogenetic analysis of the early bats, including analysis of characters. The material here described and figured is sufficient to distinguish the taxa and necessary for their systematic attribution.

Abbreviations of institutes housed material from Vastan: GU/RSR/VAS - Garhwal University, Srinigar; IITR/SB/ VLM-Indian Institute of Technology, Roorkee.

\section{Systematic palaeontology}

\section{Order Chiroptera Blumenbach 1779}

Sub-order Microchiropteramorpha Simmons and Geisler 1998

Family Icaronycteridae Jepsen 1966

Genus Icaronycteris Jepsen 1966

Icaronycteris sigei $\mathrm{sp}$. nov.

Etymology For French palaeontologist Bernard Sigé, in recognition of his contributions to knowledge of early European and African bats.

Holotype GU/RSR/VAS 137 (Fig. 1a), nearly complete left dentary with $\mathrm{P}_{3}-\mathrm{M}_{2}$.

Referred specimens GU/RSR/VAS 136 (Fig. 1b), left dentary with $\mathrm{M}_{1-3}$; GU/RSR/VAS 139, left dentary with $\mathrm{P}_{4}-\mathrm{M}_{3}$; GU/ RSR/VAS 194, left dentary with $\mathrm{P}_{4}-\mathrm{M}_{3}$ (Table 1).

Diagnosis Dentary shallow with narrow symphysial surface and two mental foramina, below $\mathrm{I}_{2-3}$ and below $\mathrm{P}_{2} . \mathrm{P}_{4}$ $\mathrm{M}_{3}$ with well-developed paraconids and $\mathrm{P}_{4}$ with very prominent metaconid; $\mathrm{P}_{4}$ lacks partial lingual cingulum, unlike I. mеnui. Hypoconulid of $\mathrm{M}_{1-3}$ lingually displaced and connected to entoconid by a crest. Larger (12-20\%) than I. index and I. menui; dentary behind $\mathrm{M}_{3}$ more elevated at base of ascending ramus than in I. index.

Discussion Icaronycteris has been considered to be the most plesiomorphic bat (Simmons and Geisler 1998). Its anatomy is known from exceptionally well-preserved skeletons of I. index from the Green River Formation, Wyoming

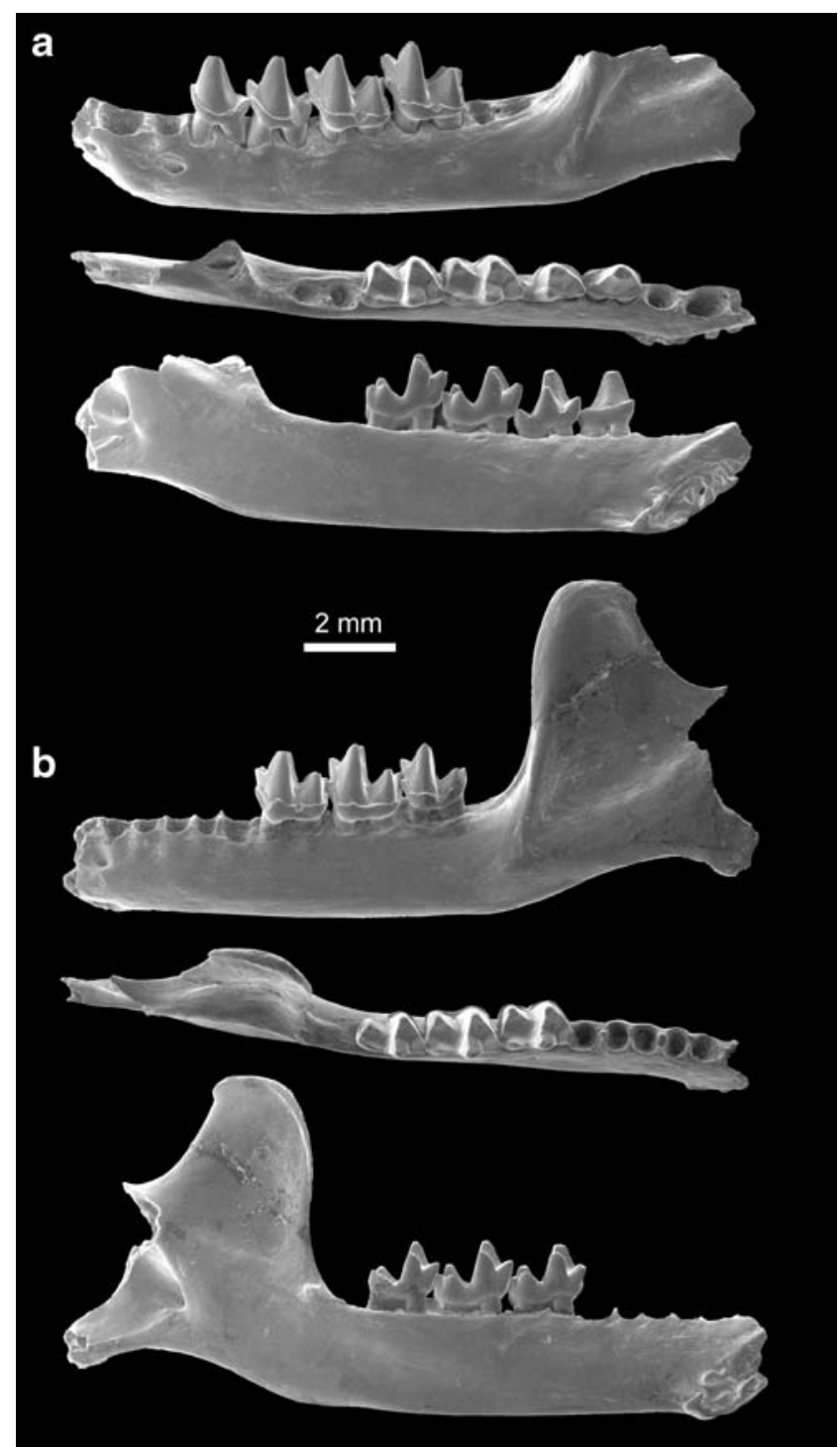

Fig. 1 Icaronycteris sigei $\mathrm{sp}$. nov. a dentary with $\mathrm{P}_{3}-\mathrm{M}_{2}(\mathrm{GU} / \mathrm{RSR} /$ VAS 137), b dentary with $\mathrm{M}_{1-3}$ (GU/RSR/VAS 136) in labial, occlusal, and lingual views

(Jepsen 1966; Simmons and Geisler 1998) and from isolated teeth of I.? menui from Mutigny and Avenay, France (Russell et al. 1973). We confirm here that the holotype and most of the teeth referred to I.? menui from Mutigny belong to the genus Icaronycteris. However, the material from Avenay is probably represented by a mix of two taxa. One of them appears to represent Icaronycteris, whereas the second indicates another genus more derived by the postcristid joining hypoconid to hypoconulid, with a notch between the entoconid and the hypoconulid (nyctalodonty).

Family Archaeonycteridae Revilliod 1917

Protonycteris gunnelli gen. et sp. nov.

Etymology The generic name refers to the primitive molar morphology of this bat; the species' name is for American 
Table 1 Measurements of the figured specimens (in $\mathrm{mm}$ )

\begin{tabular}{|c|c|c|c|c|c|}
\hline \multirow{2}{*}{ Specimen number } & \multirow[t]{2}{*}{ Description } & \multicolumn{2}{|c|}{ Position } & \multicolumn{2}{|c|}{ Measurements } \\
\hline & & Len & & Width & \\
\hline Icaronycteris sigei & & & & Trigonid & Talonid \\
\hline \multirow[t]{4}{*}{ GU/RSR/VAS 137} & Left dentary with $\mathrm{P}_{3}-\mathrm{M}_{2}$ (holotype) & $\mathrm{P}_{3}$ & 1.30 & & \\
\hline & & $\mathrm{P}_{4}$ & 1.50 & & \\
\hline & & $\mathrm{M}_{1}$ & 1.80 & 1.15 & 1.10 \\
\hline & & $\mathrm{M}_{2}$ & 1.80 & 1.20 & 1.10 \\
\hline \multirow[t]{3}{*}{ GU/RSR/VAS 136} & Left dentary with $\mathrm{M}_{1-3}$ & $\mathrm{M}_{1}$ & 1.70 & 1.15 & 1.10 \\
\hline & & $\mathrm{M}_{2}$ & 1.75 & 1.20 & 1.10 \\
\hline & & $\mathrm{M}_{3}$ & 1.55 & 1.05 & 0.75 \\
\hline \multicolumn{6}{|c|}{ Protonycteris gunnelli gen. et sp. nov. } \\
\hline \multirow[t]{5}{*}{ GU/RSR/VAS 436} & Left dentary with $\mathrm{P}_{3}-\mathrm{M}_{3}$ (holotype) & $\mathrm{P}_{3}$ & 1.65 & & \\
\hline & & $\mathrm{P}_{4}$ & 1.75 & & \\
\hline & & $\mathrm{M}_{1}$ & 2.00 & 1.40 & 1.40 \\
\hline & & $\mathrm{M}_{2}$ & 2.10 & 1.50 & 1.40 \\
\hline & & $\mathrm{M}_{3}$ & 1.90 & 1.35 & 1.05 \\
\hline \multicolumn{6}{|c|}{ Archaeonycteris storchi sp. nov. } \\
\hline \multirow[t]{3}{*}{ GU/RSR/VAS 140} & Right dentary fragment with $\mathrm{P}_{4}-\mathrm{M}_{2}$ (holotype) & $\mathrm{P}_{4}$ & 1.35 & & \\
\hline & & $\mathrm{M}_{1}$ & 1.50 & 0.95 & 1.00 \\
\hline & & $\mathrm{M}_{2}$ & 1.55 & 1.05 & 1.00 \\
\hline \multicolumn{6}{|c|}{ Hassianycteris kumari sp. nov. } \\
\hline GU/RSR/VAS 59 & Left $\mathrm{P}_{4}$ & & 1.80 & & \\
\hline GU/RSR/VAS 61 & Right lower canine & & 1.65 & & \\
\hline GU/RSR/VAS 56 & Right $\mathrm{M}_{1}$ or $\mathrm{M}_{2}$ & & 2.35 & 1.40 & 1.65 \\
\hline GU/RSR/VAS 561 & Left $\mathrm{M}_{1}$ or $\mathrm{M}_{2}$ & & 2.30 & - & 1.40 \\
\hline \multicolumn{6}{|c|}{ Cambaya complexus Bajpai et al. 2005a } \\
\hline \multirow[t]{4}{*}{ GU/RSR/VAS 435} & Right dentary with $\mathrm{P}_{4}-\mathrm{M}_{3}$ & $\mathrm{P}_{4}$ & 1.35 & & \\
\hline & & $\mathrm{M}_{1}$ & 1.75 & 1.00 & 1.05 \\
\hline & & $\mathrm{M}_{2}$ & 1.75 & 1.15 & 1.10 \\
\hline & & $\mathrm{M}_{3}$ & 1.60 & 1.10 & 0.80 \\
\hline \multicolumn{6}{|c|}{ Microchiropteryx folieae gen. et sp. nov. } \\
\hline GU/RSR/VAS 96 & Left dentary frag. with $\mathrm{M}_{3}$ & $\mathrm{M}_{3}$ & 1.00 & 0.60 & 0.50 \\
\hline \multirow[t]{2}{*}{ GU/RSR/VAS 459} & Right dentary frag. with $\mathrm{M}_{1}$ and $\mathrm{M}_{3}$ & $\mathrm{M}_{1}$ & 1.20 & 0.60 & 0.70 \\
\hline & & $\mathrm{M}_{3}$ & 1.10 & 0.60 & 0.55 \\
\hline \multicolumn{6}{|c|}{ Jaegeria cambayensis Bajpai et al. 2005b } \\
\hline \multirow[t]{2}{*}{ GU/RSR/VAS 458} & Left dentary frag. with $\mathrm{P}_{4}-\mathrm{M}_{1}$ & $\mathrm{P}_{4}$ & 1.00 & & \\
\hline & & $\mathrm{M}_{1}$ & 1.35 & 0.90 & 0.95 \\
\hline \multirow[t]{2}{*}{ GU/RSR/VAS 100} & Left dentary frag. with $\mathrm{M}_{2-3}$ & $\mathrm{M}_{2}$ & 1.35 & 0.95 & 0.90 \\
\hline & & $\mathrm{M}_{3}$ & 1.25 & 0.85 & 0.70 \\
\hline
\end{tabular}

GU/RSR/VAS Garhwal University/Rajendra Singh Rana/Vastan

palaeontologist Gregg Gunnell for his contributions on early bat phylogeny.

Holotype and only known specimen GU/RSR/VAS 436 (Fig. 2a), nearly complete left dentary with $\mathrm{P}_{3}-\mathrm{M}_{3}$.

Diagnosis Lower molars short, wide, with posterolabially incomplete ectocingulum, strong hypoconid, relatively weak entoconid, slightly lingually shifted hypoconulid, short and weak oblique crest. $\mathrm{P}_{4}$ with small, low paraconid, and prominent metaconid with long posterior crest. Two mental foramina present, below $\mathrm{I}_{3}$ and below front of $\mathrm{P}_{2}$; narrow symphysis. About the size of Archaeonycteris trigonodon but differs from it in having wider lower molars, incomplete labial cingulum, and more central hypoconulid.

Discussion Protonycteris is referred to archaeonycterid bats because of the weak entoconid, relatively labial oblique crest on the lower molars, and well-developed metaconid on $\mathrm{P}_{4}$. Protonycteris is plesiomorphic in the position of the hypoconulid. However, $\mathrm{P}_{4}$ appears to be derived relative to Icaronycteris in having less well-developed paraconid, metaconid, and talonid. 

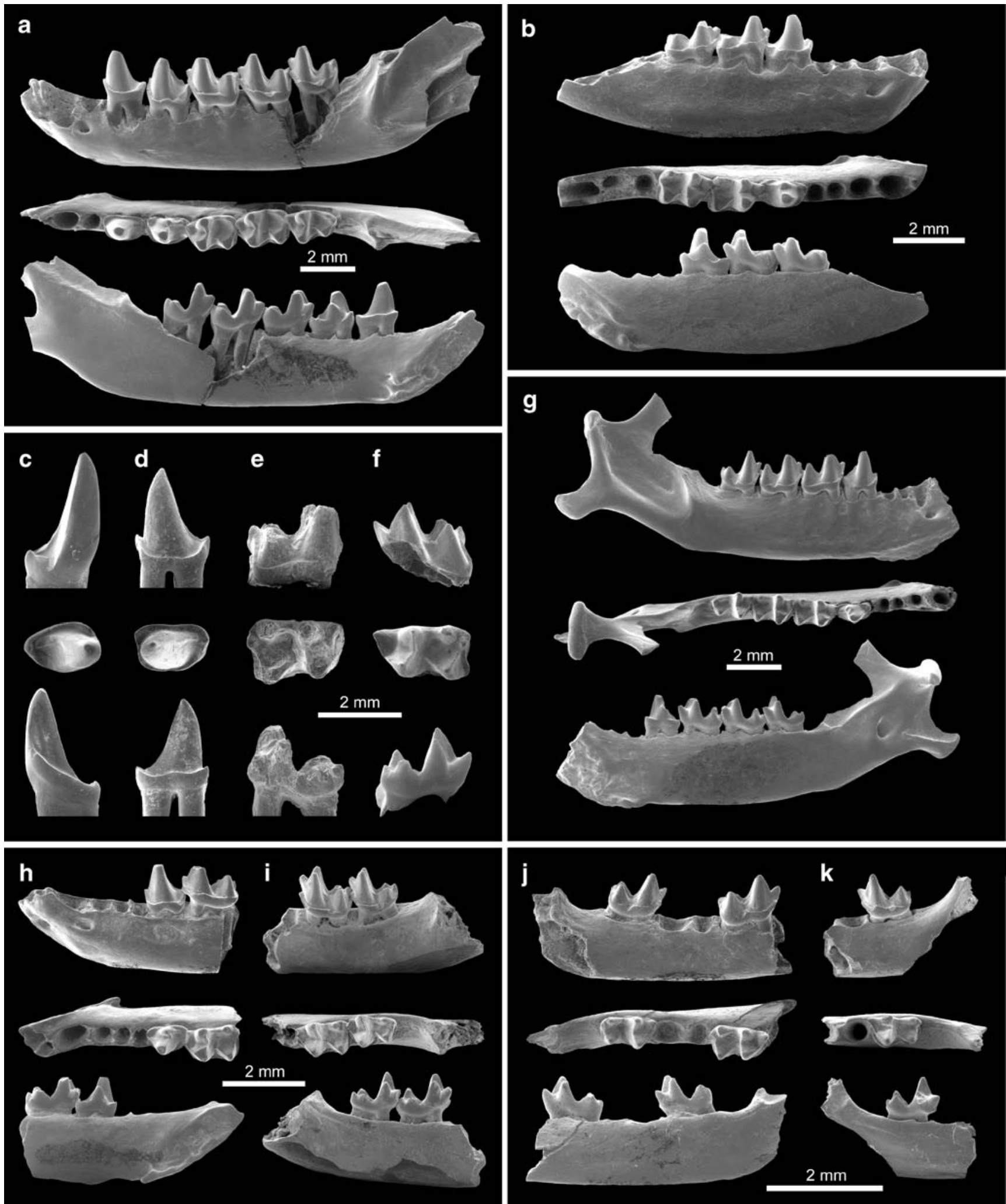

Fig. 2 a Protonycteris gunnelli gen. et sp. nov., dentary with $\mathrm{P}_{3}-\mathrm{M}_{3}$ (GU/RSR/VAS 436); b Archaeonycteris? storchi sp. nov., dentary fragment with $\mathrm{P}_{4}-\mathrm{M}_{2}$ (GU/RSR/VAS 140); c-f Hassianycteris kumari sp. nov. c lower canine (GU/RSR/VAS 61), d $\mathrm{P}_{4}$ (GU/RSR/VAS 59), e $\mathrm{M}_{1}$ or $\mathrm{M}_{2}(\mathrm{GU} / \mathrm{RSR} / \mathrm{VAS} 56), \mathbf{f} \mathrm{M}_{1}$ or $\mathrm{M}_{2}$ (GU/RSR/VAS 561); $\mathbf{g}$

Cambaya complexus, dentary with $\mathrm{P}_{4}-\mathrm{M}_{3}$ (GU/RSR/VAS 435); $\mathbf{h}-\mathbf{i}$ Jaegeria cambayensis $\mathbf{h}$ dentary fragment with $\mathrm{P}_{4}-\mathrm{M}_{1}(\mathrm{GU} / \mathrm{RSR} / \mathrm{VAS}$ 458), i dentary fragment with $\mathrm{M}_{2-3}$ (GU/RSR/VAS 100); $\mathbf{j}-\mathbf{k}$ Microchiropteryx folieae gen. et sp. nov. $\mathbf{j}$ dentary fragment with $\mathrm{M}_{1}$ and $\mathrm{M}_{3}$ (GU/RSR/VAS 459), $\mathbf{k}$ dentary fragment with $\mathrm{M}_{3}$ (GU/RSR/VAS 96) 
Archaeonycteris? Revilliod 1917

Archaeonycteris? storchi sp. nov.

Etymology For German palaeontologist Gerhard Storch, in recognition of his contributions to the knowledge of early European bats.

Holotype GU/RSR/VAS 140 (Fig. 2b), right dentary fragment with $\mathrm{P}_{4}-\mathrm{M}_{2}$.

Referred specimen GU/RSR/VAS 135, left dentary fragment with $\mathrm{M}_{1-3}$.

Diagnosis 35\% smaller than Archaeonycteris brailloni, and 20-25\% smaller than A. trigonodon and Protonycteris gunnelli. Differs from A. brailloni by the absence of a paracristid on $\mathrm{P}_{4}$ and from $P$. gunnelli in having a somewhat deeper dentary, lower paraconid and metaconid on $\mathrm{P}_{4}$, higher length/width ratio on lower molars, and more distinct and relatively stronger entoconid and hypoconulid with a deeper talonid basin.

Discussion This species is referred to archaeonycterid bats for the same reasons noted above for Protonycteris gunnelli, but it shares most of the characters with the genus Archaeonycteris. However, the absence in A.? storchi of a paracristid on $\mathrm{P}_{4}$, which is present on $\mathrm{P}_{4}$ of $A$. brailloni from Avenay (Russell et al. 1973), represents a more advanced state. A detailed analysis of the dental characters of Archaeonycteris should help to ascertain the generic attribution of $A$ ? storchi.

Family Hassianycterididae Habersetzer and Storch 1987 Genus Hassianycteris Smith and Storch 1981

Hassianycteris kumari sp. nov.

Etymology For Indian palaeontologist Kishor Kumar, for his contributions to the knowledge of Indian Eocene mammal faunas.

Holotype GU/RSR/VAS 59 (Fig. 2d), a left $\mathrm{P}_{4}$.

Referred specimens $\mathrm{GU} / \mathrm{RSR} / \mathrm{VAS}$ 60, left $\mathrm{P}_{4} ; \mathrm{GU} / \mathrm{RSR} /$ VAS 132, right $\mathrm{P}_{4}$; GU/RSR/VAS 61 (Fig. 2c), right lower canine; GU/RSR/VAS 56 (Fig. 2e), right $\mathrm{M}_{1}$ or $\mathrm{M}_{2}$; GU/ RSR/VAS 561 (Fig. 2f), left $\mathrm{M}_{1}$ or $\mathrm{M}_{2}$.

Diagnosis Canine tall, $\mathrm{P}_{4}$ tall and premolariform, molars nyctalodont with wide talonid on $\mathrm{M}_{1-2}$ and strong entoconid. About the size of $H$. magna, $12-15 \%$ larger than $H$. messelensis and $H$. revilliodi, and $35 \%$ larger than "Hassianycteris" joeli. Differs from those species in having straighter ectocingulum on $\mathrm{P}_{4}$ and from $H$. revilliodi in having taller canine and $\mathrm{P}_{4}$.

Discussion This is the largest bat from Vastan. It is most similar to $H$. magna from the early Lutetian of Messel (Germany) and presents the typical derived characters for the genus Hassianycteris, including tall premolariform $\mathrm{P}_{4}$, tall and straight lower canine, nyctalodont lower molars with wide talonid and well-developed entoconid. $H$. joeli from the late Ypresian of Belgium (Smith and Russell 1992) differs from other species of Hassianycteris by its small size, reduced $P_{4}$, narrow $M_{1}$, relatively central hypoconulid, and weak development of nyctalodonty. These characters are shared with Honrovits tsuwape, the oldest natalid bat from the late Early Eocene of Wyoming (Beard et al. 1992).

Family Hassianycterididae? Habersetzer and Storch 1987

Genus Cambaya Bajpai et al. 2005a

Cambaya complexus Bajpai et al. 2005a

Holotype IITR/SB/VLM 508, isolated left $\mathrm{P}_{4}$.

Referred specimen GU/RSR/VAS 435 (Fig. 2g), nearly complete right dentary with $\mathrm{P}_{4}-\mathrm{M}_{3}$.

Emended diagnosis Dentary relatively deep, with wide, anteroventrally expanded symphysis and large mental foramen situated between $\mathrm{C}$ and $\mathrm{P}_{2}$. $\mathrm{P}_{4}$ with very low paraconid, long crest at back of prominent metaconid, short talonid, and incomplete lingual cingulum. Molars narrow and nyctalodont with long cristid obliqua, relatively low hypoconulid, high entoconid on $\mathrm{M}_{1-2}$, and complete ectocingulum.

Discussion Bajpai et al. (2005a) described a $\mathrm{P}_{4}$ from Vastan that they attributed to the first nyctitheriid insectivore from India. Although the tooth resembles $\mathrm{P}_{4}$ of the Asian nyctitheriid Bumbanius, it more closely conforms to typical bat morphology, with a complete ectocingulum and a partial lingual cingulum mirroring those of $\mathrm{P}_{4}$ in $\mathrm{GU} /$ RSR/VAS 435. Unfortunately, the holotype is a single tooth, but the more complete specimen described here eliminates any doubt that Cambaya is chiropteran, not nyctitheriid. Cambaya complexus presents several derived features such as the reduced paraconid and talonid on $\mathrm{P}_{4}$, the development of the nyctalodonty on the lower molars, and a deeper dentary than in all other Vastan bats except perhaps Hassianycteris. These derived characters exclude allocation to Icaronycteridae or Archaeonycteridae. In some features, Cambaya resembles Palaeochiropterygidae, but the morphology of $\mathrm{M}_{3}$ and the deep dentary with expanded 
symphysis are not typical of that family. The derived characters of $C$. complexus are present in Hassianycterididae, whereas the semi-molariform morphology of $\mathrm{P}_{4}$ distinguishes C. complexus from Hassianycteris. C. complexus may represent a more primitive state than Hassianycteris.

Family Palaeochiropterygidae Revilliod 1917

Microchiropteryx folieae gen. et sp. nov.

Etymology The generic name refers to the very small size of this bat; the species name is for Belgian palaeontologist Annelise Folie for her contribution to the Indian Eocene vertebrate project.

Holotype GU/RSR/VAS 96 (Fig. 2k), left dentary fragment with $\mathrm{M}_{3}$.

Referred specimens GU/RSR/VAS 459 (Fig. 2j), right dentary fragment with $\mathrm{M}_{1}$ and $\mathrm{M}_{3}$.

Diagnosis Lower molars very small, long and narrow, and strongly nyctalodont. $\mathrm{M}_{3}$ with well-basined, square talonid, entocristid parallel to the long axis of the tooth, and postcristid perpendicular to the long axis of the tooth. Differs from Palaeochiropteryx tupaiodon and P. spiegeli in having narrower lower molars and more labial cristid obliqua.

Discussion This very small bat is rare in Vastan. It is referred to Palaeochiropterygidae because of its small size, narrow, nyctalodont lower molars, well-developed anteroposteriorly elongated entoconid, and the orientation of the $\mathrm{M}_{3}$ entocristid and postcristid. These last two characters result in the square shape of the talonid similar to that of $\mathrm{M}_{3}$ in Palaeochiropteryx, Cecilionycteris, and Lapichiropteryx. Microchiropteryx, however, is much smaller than the other genera.

Family indet.

Genus Jaegeria Bajpai et al. 2005b

Jaegeria cambayensis Bajpai et al. 2005b

Holotype IITR/SB/VLM/585, left $\mathrm{M}_{1}$ or $\mathrm{M}_{2}$.

Referred specimens GU/RSR/VAS 458 (Fig. 2h), left dentary fragment with $\mathrm{P}_{4}-\mathrm{M}_{1}$; GU/RSR/VAS 100 (Fig. 2i), left dentary fragment with $\mathrm{M}_{2-3}$.

Emended diagnosis Dentary shallow with two mental foramina, below $\mathrm{I}_{3}$ and below the back of the C. alveolus. $\mathrm{P}_{4}$ with low paraconid, well-developed metaconid, and short, rounded talonid. $\mathrm{M}_{1-3}$ nyctalodont with very lingual hypoconulid just posterior to entoconid and long cristid obliqua forming an acute angle with the posterior crest. $\mathrm{M}_{3}$ with somewhat reduced talonid basin.

Discussion Bajpai et al. (2005b) described a few lower teeth from Vastan as the first fossil marsupials of India, including one lower molar attributed to peradectines and one lower molar and three tooth fragments attributed to herpetotheriines. However, comparisons with the bats described here indicate that the holotype and only complete tooth of the purported herpetotheriine Jaegeria cambayensis is a left $\mathrm{M}_{1}$ or $\mathrm{M}_{2}$ of a nyctalodont bat; additionally, more complete specimens are referred to the species here. The diagnostic characters of $J$. cambayensis indicate that it is not referable to Icaronycteridae, Archaeonycteridae, or Hassianycterididae. It might belong to a primitive palaeochiropterygid, a new family, or perhaps an extant family.

\section{Diversity and affinities of Early Eocene Indian bats}

The bat fauna from Vastan is the earliest known from both India and Asia. Surprisingly, it also represents the most diverse known Early Eocene bat fauna. However, none of the seven Vastan bats seems to belong to an extant family, with the possible exception of $J$. cambayensis, which has not been definitively identified at the family level.

Where known, all these bats seem to have a lower jaw with three incisors, three premolars, and an elongate angular process (Simmons and Geisler 1998). Of the seven species, three are particularly primitive (Icaronycteris sigei, Protonycteris gunnelli, and Archaeonycteris? storchi) based on having an unreduced metaconid on $\mathrm{P}_{4}$ and tribosphenic molars that are not yet nyctalodont (Russell and Sigé 1970). The new genus Protonycteris is phylogenetically significant because it has an incomplete ectocingulum and a nearly central hypoconulid on the talonid basin. The presence of an ectocingulum and lingual displacement of the hypoconulid has been considered important synapomorphies of bat molars, and their incipient development in Protonycteris indicates its very plesiomorphic position.

The four other species (Hassianycteris kumari, Cambaya complexus, Jaegeria cambayensis, and Microchiropteryx folieae) are more derived in having nyctalodont teeth. $J$. cambayensis and M. folieae are well advanced in nyctalodonty and could represent precursors to myotodonty (in which the postcristid runs to the entoconid) based on the hypoconulid being almost fully lingual and just posterior to the entoconid. This last condition is especially evident on the $\mathrm{M}_{3}$ of M. folieae.

The resemblance of the Indian bat fauna from Vastan to Eocene European bat faunas is astonishing. This is especially the case with the bats from the late Early Eocene of the Paris Basin (Russell et al. 1973) and the early Middle 
Eocene of the German Messel locality (Habersetzer and Storch 1987; Storch et al. 2002). The similarity could simply result from the fact that most Eocene bats are European and early Eocene Asian bat faunas are unknown (Gunnell and Simmons 2005). The only Asian genus close to the Indian taxa is Lapichiropteryx from the late Middle Eocene of Yuanqu Basin, China (Tong 1997). This palaeochiropterygid bat shares several characters with Microchiropteryx, but comparison below the family level is difficult because Microchiropteryx is insufficiently known. The poorly diversified North American bat faunas and the absence of bats in Early Eocene Central Asian faunas may also suggest new palaeobiogeographic scenarios implicating the relative position of India and connections with Europe during the Early Eocene.

Acknowledgments We thank our colleagues who participated in the Vastan paleontological expeditions of 2004 and 2006, including K. Kumar, P. K. Saraswati, S. Tripathi, N. Sahni, A. Folie, G. McKusick, and M. Chaudhary; Mr. Amarnath (manager) and the mining staff of Gujarat Industrial Power Corporation for help at Vastan Mine; G. Gunnell, R. Smith, P. Tassy, C. Sagne, S. Zack, J. Habersetzer, N. Micklich, and N. Simmons for giving access to comparative material, providing casts and pictures, molding and casting and other assistance, or discussion about fossil bats; B. Sigé and G. Gunnell for improving the manuscript; J. Cillis (RBINS) for the SEM photographs. Fieldwork has been sponsored by National Geographic Grants 6868-00 and 793805 to Rose and Sahni. This paper is a contribution to project MO/36/011 financially supported by the Belgian Federal Science Policy Office.

\section{References}

Bajpai S, Kapur VV, Das DP, Tiwari BN, Saravanan N, Sharma R (2005a) Early Eocene land mammals from Vastan Lignite Mine, District Surat (Gujarat), western India. J Palaeontol Soc India 50:101-113

Bajpai S, Kapur VV, Thewissen JGM, Tiwari BN, Das DP (2005b) First fossil marsupial from India: early Eocene Indodelphis n. gen. and Jaegeria n. gen. from Vastan Lignite Mine, District Surat, Gujarat. J Palaeontol Soc India 50:147-151
Beard KC, Sigé B, Krishtalka L (1992) A primitive vespertilionoid bat from the early Eocene of central Wyoming. CR Acad Sci II 314:735-741

Gunnell GF, Simmons NB (2005) Fossil evidence and the origin of bats. J Mamm Evol 12:209-246

Habersetzer J, Storch G (1987) Klassifikation und funktionelle Flügelmorphologie paläogener Fledermäuse (Mammalia, Chiroptera). Cour Forsch-Inst Senckenberg 91:117-150

Hand S, Novacek M, Godthelp H, Archer M (1994) First Eocene bat from Australia. J Vertebr Paleontol 14:375-381

Jepsen GL (1966) Early Eocene bat from Wyoming. Science 154:1333-1339

Rana RS, Singh H, Sahni A, Rose KD, Saraswati PK (2005) Early Eocene chiropterans from a new mammalian assemblage (Vastan Lignite Mine, Gujarat, western peninsular margin): oldest known bats from Asia. J Palaeontol Soc India 50(1):93-100

Rose KD, Smith T, Rana RS, Sahni A, Singh H, Missiaen P, Folie A (2006) Early Eocene (Ypresian) continental vertebrate assemblage from India, with description of a new anthracobunid (Mammalia, Tethytheria). J Vert Paleontol 26(1):219-225

Russell DE, Sigé B (1970) Révision des chiroptères lutétiens de Messel (Hesse, Allemagne). Palaeovertebrata 3:83-182

Russell DE, Gingerich PD (1981) Lipotyphla, Proteutheria(?), and Chiroptera (Mammalia) from the early-middle Eocene Kuldana formation of Kohat (Pakistan). Contrib Mus Paleontol Univ Michigan 25:277-287

Russell DE, Louis P, Savage DE (1973) Chiroptera and Dermoptera of the French Early Eocene. Univ Calif Publ Geol Sci 95:1-57

Sigé B (1991) Rhinolophoidea et Vespertilionoidea (Chiroptera) du Chambi (Eocène inférieur de Tunisie). Aspects biostratigraphique, biogéographique et paléoécologique de l'origine des chiroptères modernes. N Jb Geol Paläontol Abh 182(3):355-376

Simmons NB, Geisler JH (1998) Phylogenetic relationships of Icaronycteris, Archaeonycteris, Hassianycteris, and Palaeochiropteryx to extant bat lineages, with comments on the evolution of echolocation and foraging strategies in Microchiroptera. Bull Am Mus Nat Hist 235:182

Smith R, Russell DE (1992) Mammifères (Marsupialia, Chiroptera) de l'Yprésien de la Belgique. Bull Inst R Sci Natl Belg, Sciences de la Terre 62:223-227

Storch G, Sigé B, Habersetzer J (2002) Tachypteron franzeni n. gen., n. sp., earliest emballonurid bat from the Middle Eocene of Messel (Mammalia, Chiroptera). Palaeont Zeit 76:189-199

Tong Y-S (1997) Middle Eocene small mammals from Liguanqiao Basin of Henan Province and Yuanqu Basin of Shanxi Province, Central China. Palaeontol Sinica 18, New Series C 26:256 